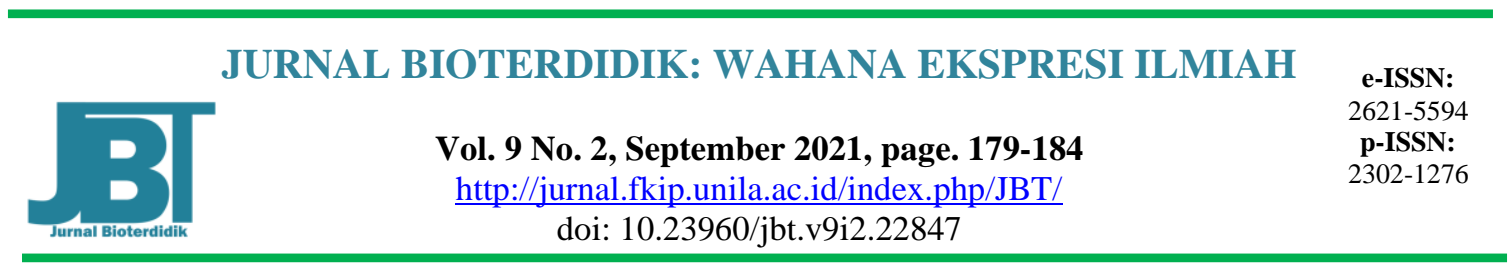

\title{
Pengembangan Majalah Sains Digital Berbasis Literasi Sains Pada Materi Pemanasan Global Untuk Siswa Kelas VII Di SMP Negeri 1 Rambipuji
}

\author{
Mahdia Fitria*, Mohammad Wildan Habibi \\ Prodi Tadris IPA, Fakultas Tarbiyah dan Ilmu Keguruan, Universitas Islam Negeri K.H Achmad Siddiq, \\ Jl. Mataram No. 1 Mangli, Jember 68136, Indonesia \\ *e-mail: fitriamahdia@gmail.com
}

Abstract: Development of a Digital Science Magazine Based on Science Literacy on Global Warming Materials for Class VII Students at SMP Negeri 1 Rambi Puji. This study aims to obtain information on product validation of science literacy-based science magazines in science learning about global warming in class VII and to describe students' responses to science magazines based on scientific literacy in science learning on the subject of global warming in class VII. This study uses an R\&D (Research \& Development) development approach with the Hannafin and Peck model which has three learning designs, namely needs analysis (needs assess), design (design), development/ implementation (develop/ implement). The result showed that science literacy-based science magazine teaching materials based on the assessment of material experts met the validation criteria of $95 \%$, media experts met the validation criteria of $86,15 \%$, and student responses stated that they were interesting $87,11 \%$, so that the teaching materials developed met the criteria valid and attractive criteria.

Keywords: global warming, science magazine, science literacy

\begin{abstract}
Abstrak: Pengembangan Majalah Sains Digital Berbasis Literasi Sains Pada Materi Pemanasan Global Untuk Siswa Kelas VII Di SMP Negeri 1 Rambipuji. Penelitian ini bertujuan untuk memperoleh informasi mengenai validasi produk majalah sains berbasis literasi sains dalam pembelajaran IPA pokok bahasan pemanasan global kelas VII dan mendeskripsikan respon siswa mengenai majalah sains berbasis literasi sains pada pembelajaran IPA pokok bahasan pemanasan global kelas VII. Penelitian ini menggunakan pendekatan pengembangan R\&D (Research \& Development) yang menggunakan model Hannafin and Peck yang memiliki tiga desain pembelajaran yaitu analisis ebutuhan (needs assess), desain (Design), pengembangan/ Implementasi (Develop/ Implement). Hasil penelitian menunjukkan bahwa bahan ajar majalah sains berbasis literasi sains berdasarkan evaluasi ahli materi memenuhi kriteria validasi yaitu sebesar 95\%, ahli media memenuhi kriteria validasi sebesar $86,15 \%$, dan respon siswa menyatakan menarik $87,11 \%$, sehingga bahan ajar majalah sains yang dikembangkan telah memenuhi kriteria valid dan menarik.
\end{abstract}

Kata kunci: literasi sains, majalah sains, pemanasan global 


\section{PENDAHULUAN}

Pendidikan merupakan suatu usaha untuk membangun jiwa anak didik baik lahir dan juga batin, dari sifat kodratinya mengarah ke peradaban manusiawi yang lebih baik, serta proses yang berkelanjutan dan tidak pernah berakhir (never ending proces), kemudian bisa menghasilkan kualitas yang berkesinambungan, yang ditujukan dalam perwujudan sosok manusia masa depan, yang berakar pada nilai-nilai budaya bangsa serta Pancasila (Sujana 2019). Pendidikan nasional bermaksud untuk membangun potensi siswa supaya menjadi manusia yang beriman dan bertaqwa kepada Tuhan Yang Maha Esa, berakhlak mulia, sehat, berilmu, cakap, kreatif, mandiri serta menjadi warga negara yang demokratis juga bertanggung jawab (Departemen Pendidikan Nasional 2006)

Banyak faktor yang mempengaruhi proses pembelajaran yang mengakibatkan siswa kesulitan dalam memahami materi. Hal ini mengakibatkan mereka mencari sumber belajar yang lain. Oleh karenanya siswa mencoba untuk belajar mandiri menggunakan bantuan sumber belajar yang sesuai keinginan yaitu dengan cara menyediakan sarana belajar yang menarik, sehingga akan bisa memotivasi siswa belajar IPA (Yulianto E. 2013).

Pembelajaran yang berada di Indonesia pada saat ini sedang menghadapi tantangan. Tantangan yang pertama perubahan persepsi mengenai belajar dan tantangan kedua pada teknologi informasi dan telekomunikasi (TIK) yang menunjukkan perkembangan luar biasa.

Hasil penggalian informasi yang dilakukan dengan salah satu guru IPA di SMP Negeri 1 Rambipuji untuk materi pemanasan global kurang tersampaikan secara maksimal yang disebabkan oleh beberapa kendala meliputi: pertama, guru lebih mendominasi saat aktivitas belajar mengajar dengan ceramah pada materi ini. Kedua, tidak adanya literasi pendukung pemahaman materi berupa bahan ajar yang bisa menunjang penangkapan siswa pada materi ini. Ketiga, kurangnya minat baca siswa sehingga literasi yang dimiliki siswa juga kurang. Ada banyak penelitian dalam berbagai jurnal tentang strategi untuk memahamkan materi pemanasan global pada siswa. Meskipun beragam penelitian mengenai strategi pembelajaran pada materi pemanasan global masih banyak miskonsepsi siswa terkait materi ini. Kesulitan siswa dalam pemahaman materi pemanasan global diharapkan bisa diatasi dengan bahan ajar yang lebih menarik.

Salah satu pendukung pada suatu kesuksesan proses pembelajaran di sekolah yaitu dengan adanya bahan ajar. Majalah berbasis digital dapat menjadi salah satu solusinya. Peneliti berupaya mengembangkan bahan ajar yang mempermudah siswa dan guru dalam mempelajari dan menyampaikan materi, maka dikembangkan bahan ajar berupa majalah sains. Majalah secara global diartikan sebagai media informasi yang tugas utamanya untuk menyampaikan berita aktual. Pada konteks pendidikan didalam sekolah seharusnya menyediakan berbagai jenis bahan ajar berbasis majalah yang dapat menciptakan lingkungan belajar secara aktif dan mampu membantu siswa untuk membangun konsep IPA yang sesuai dengan kecepatan belajarnya siswa (Munadi 2012).

Bahan ajar majalah akan dibalut dengan literasi sains yang dikemas semenarik mungkin supaya siswa tidak merasa bosan saat materi pemanasan global. Literasi sains diartikan sebagai kemampuan berpikir secara ilmiah yang menggunakan pengetahuan serta proses sains untuk memahami fenomena alam sehingga mampu mengambil keputusan untuk memecahkan masalah sains yang dihadapi (Khoirul Arief 2015). 
Berdasarkan latar belakang yang telah dipaparkan, maka penelitian ini bertujuan untuk mengetahui validitas dan respon siswa terhadap pengembangan bahan ajar majalah sains digital berbasis literasi sains kelas VII pada materi pemanasan global.

\section{METODE}

Penelitian ini termasuk ke dalam suatu penelitian dan pengembangan atau dikenal dengan Research and Development. Yaitu penelitian yang dilakukan mulai dari tingkat yang rendah ke satu tingkat yang lebih tinggi untuk mengeksplorasi produk yang sudah ada. metode penelitian dan pengembangan merupakan suatu metode penelitian yang pada akhirnya digunakan untuk menghasilkan produk tertentu, dan menguji keefektifan produk serta mengembangkan dan memvalidasi produk dalam pendidikan tersebut. Pendapat tersebut dijadikan acuan diterapkannya $\mathrm{R} \& \mathrm{D}$ pada penelitian ini yang memiliki tujuan guna membuat sebuah produk guna memecahkan masalah pada siswa. Model penelitian mengacu pada Hannafin and Peck (Muhammad and Badarudin 2011) yang memiliki tiga fase (Needs Assess, Design, Develop/Implement)

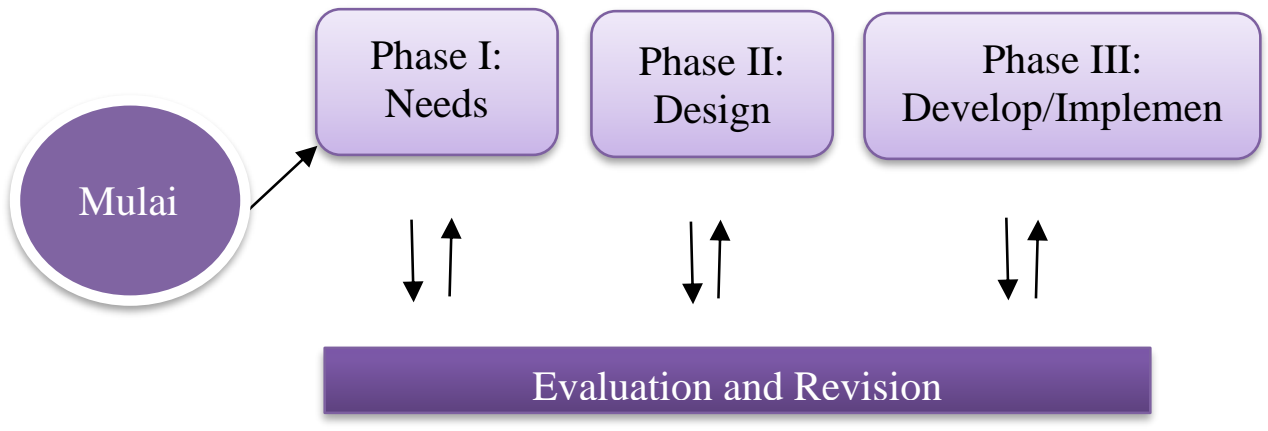

Gambar 1. Fase Penelitian.

Yang mana pada model ini, evaluasi dan pengulangan perlu dilakukan pada setiap fase. Model ini merupakan model desain pembelajaran yang berorientasi produk. Yang bertujuan untuk menguji kelayakan majalah sains berbasis literasi sains serta untuk mengetahui respons siswa terhadap pengembangan majalah sains berbasis literasi sains.

Fase pertama dari model Hannafin dan Peck yaitu analisis kebutuhan. Dibutuhkan guna mengidentifikasi kebutuhan pada saat mengembangkan sebuah media pembelajaran dengan rencana yang objektif pada media pembelajaran yang dilakukan, wawasan dan kecakapan yang dibutuhkan kelompok sasaran, peralatan juga kebutuhan media pembelajaran. Setelah semua kebutuhan diidentifikasi Hannafin dan Peck mementingkan untuk melakukan evaluasi terhadap hasil sebelum melanjutkan ke tahap selanjutnya.

Fase yang kedua yaitu fase desain. Dalam fase ini informasi pada fase analisis dijadikan bentuk dokumen yang dibuat tujuan pembuatan media tersebut. Fase desain ini mengidentifikasikan dan mendokumenkan kaidah yang paling baik guna mencapai tujuan pembuatan media tersebut. Dokumen yang diwujudkan pada fase ini yaitu dokumen story board yang meliputi urutan kegiatan pengajaran berdasarkan kebutuhan pelajaran objektif yang dihasilkan dalam fase pertama. Sama halnya dengan fase pertama, evaluasi perlu dilakukan dalam fase ini sebelum dilanjutkan ke fase selanjutnya. 
Fase ketiga adalah pengembangan dan implementasi. Dalam fase ini mengahasilkan diagram alur, pengujian, juga penilaian formatif dan penilaian sumatif. Dokumen story board sebagai landasan pembuatan diagram alir yang bisa membantu proses pengerjaan media pembelajaran. Guna menilai kelancaran media yang didapatkan seperti kesinambungan link, penilaian serta pengujian dilaksanakan pada fase ini.

Pelaksanaan penelitian berada di SMP Negeri 1 Rambipuji. Waktu penelitian ini dimulai pada bulan Januari - April 2021. Penelitian pengembangan ini memakai teknik pengumpulan data dengan cara observasi, wawancara dan angket dengan subjek siswa SMP kelas VII.

\section{HASIL DAN PEMBAHASAN}

Berdasarkan hasil analisis evaluasi validasi keseluruhan yang meliputi validasi ahli materi, ahli media, dan guru IPA didapatkan data pada Tabel 1.

Tabel 1 Hasil Validasi

\begin{tabular}{|c|c|c|}
\hline No & Validator & Skor persentase \\
\hline 1 & Dosen ahli materi & $95 \%$ \\
\hline 2 & Dosen ahli media & $86,15 \%$ \\
\hline 3 & Guru & $96,8 \%$ \\
\hline \multicolumn{2}{|c|}{ Total skor persentase } & $92,65 \%$ \\
\hline
\end{tabular}

Hasil dari keseluruhan validasi yaitu 92,65\% sehingga produk bisa dinyatakan sangat valid tanpa revisi. Sesuai dengan kriteria dari akbar. Hasil penelitian ini sesuai dengan hasil penelitian yang dilakukan Yoelinda Prilia Nurasih, Suroso Mukti Leksono dan Indria Wahyuni mengenai pengembangan majalah Invertebrata mendapatkan penilaian dari ahli media dan ahli materi secara keseluruhan sebesar $97,5 \%$, berdasarkan kriteria validitas yang digunakan bahwa nilai tersebut dikategorikan sangat valid, maka dari itu dapat disimpulkan bahwa bahan ajar, majalah sangat valid digunakan dalam pembelajaran (Nurasih, Wahyuni, and Leksono 2020).

Teknik analisis data hasil validasi bermaksud untuk mengetahui kevalidan majalah sains berbasis literasi sains yang dikembangkan. Teknik yang digunakan dalam analisis data yaitu menggunakan teknik perhitungan persentase dan teknik deskripsi kualitatif yang dikembangkan oleh akbar (Akbar 2013)

Perolehan data hasil respons siswa yang dilakukan dengan uji coba kelompok kecil sebanyak 6 siswa dan kelompok besar sebanyak 30 siswa sesuai dengan kriteria pada buku sugiyono (Sugioyono 2019) pada kelas VIIB, VIID, dan VIIE SMP Negeri 1 Rambipuji. Pada uji coba kelompok skala kecil dan uji coba kelompok skala besar mengalami peningkatan. Adapun hasil uji coba kelompok skala kecil mendapatkan ratarata persentase $84,07 \%$ dengan kriteria dinyatakan sangat valid atau dapat digunakan tanpa revisi, sedangkan pada uji coba kelompok skala besar $87,11 \%$ dengan kriteria dinyatakan sangat valid atau dapat digunakan tanpa revisi. Adapun perbandingan hasil uji coba bisa dilihat pada grafik berikut ini. 


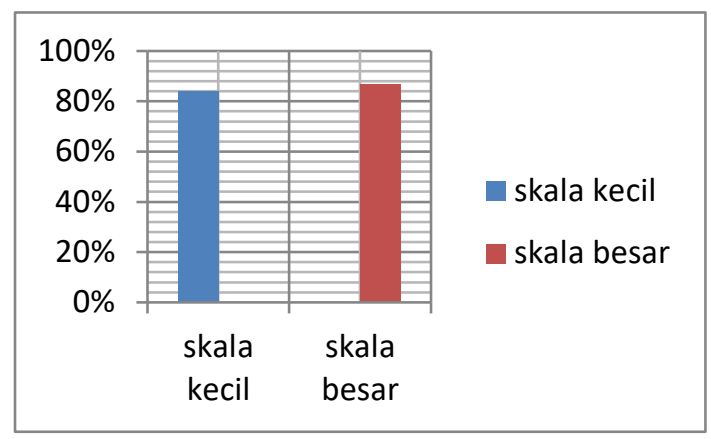

Gambar 1. Grafik Perbandingan Hasil Uji Coba Respons Siswa Kelompok Kecil dan Besar.

Berdasarkan Gambar 1 grafik perbandingan hasil uji coba kelompok kecil dan kelompok besar terlihat bahwa mengalami peningkatan sebesar 3,04\%. Majalah sains berbasis literasi sains sudah dilakukan tahap validasi dan uji coba lapangan lalu direvisi pada bagian yang perlu direvisi menurut saran dari ahli uji lapangan. Berdasarkan hasil uji coba lapangan sehingga majalah sains berbasis literasi sains layak dan mendapatkan respons positif untuk dijadikan sumber belajar.

\section{SIMPULAN}

Pengembangan majalah ini menghasilkan produk berupa majalah sains yang berbentuk PDF untuk di share ke kepada siswa. Produk yang telah dikembangkan tersebut telah memenuhi komponen sebagai bahan ajar sesuai kurikulum yang berlaku. Validasi bagian materi yang telah dilakukan oleh satu validator di dapatkan persentase kelayakan 95\%, sedangkan validasi bagian ahli media dilakukan oleh satu orang validator dan di dapatkan persentase $86,15 \%$, dan uji coba lapangan di dapatkan ratarata persentase $87,11 \%$ sehingga dapat disimpulkan bahwa bahan ajar majalah sains berbasis literasi sains yang sedang dikembangkan bisa dikategorikan sangat valid atau sangat layak digunakan pada pembelajaran. Bagi peneliti pada penelitian selanjutnya selain mengembangkan majalah sains pada materi pemanasan global kelas VII SMP/MTs, hendaklah mengadakan pengembangan bahan ajar majalah sains berbasis literasi sains pada materi yang lainnya juga bisa mempublikasikannya secara global sehingga referensi pada materi pembelajaran IPA dapat dimuat lebih efektif dan efisien serta dapat digunakan pendidik maupun peserta didik lainnya.

\section{DAFTAR RUJUKAN}

Akbar, S. (2013). Instrumen Perangkat Pembelajaran. Bandung. bandung: PT. Remaja Rosdakarya.

Arifin, Syamsul, Riyanto. (2019). "Pengembangan Majalah Anatomi Tumbuhan Sebagai Sumber Informasi Mahasiswa Di IKIP Budi Utomo Malang." Paradigma: Jurnal Filsafat, Sains, Teknologi, Dan Sosial Budaya, 25(2):34-38. doi: 10.33503/paradigma.v25i2.571.

Bantul. (2016). Pengembangan Majalah Fisika Sebagai Alternatif Sumber Belajar Menumbuhkan Sikap Spiritual Dan Motivasi Belajar Siswa Kelas Xi Development of Physic Magazine As an Alternative Islamic Character Self-Learning Resource for Growing Spiritual Attitude and Lear. Jurnal Pendidikan Fisika, 5(2):98-105. 
Departemen Pendidikan Nasional. (2006). UU RI No.20 Tahun 2003 Tentang Pendidikan Nasional. Jakarta: Depdiknas.

Fatkhriyah. (2014). Jurnal Pendidikan IPA Indonesia. Jurnal Pendidikan IPA Indonesia $3(1): 140-45$.

Global. (2014). Pengembangan Modul Ipa Terpadu Berkarakter Tema Pemanasan Global Untuk Siswa SMP/MTs. USEJ - Unnes Science Education Journal 2(1):203-8. doi: 10.15294/usej.v2i1.1824.

Hanafy. (2014). Konsep Belajar Dan Pembelajaran. Lentera Pendidikan: Jurnal Ilmu Tarbiyah Dan Keguruan 17(1):66-79. doi: 10.24252/lp.2014v17n1a5.

Khoirul, Meizuvan. (2015). "Penerapan Levels of Inquiry Pada Pembelajaran Ipa Tema Pemanasan Global Untuk Meningkatkan Literasi Sains." Edusentris, 2(2):166. doi: 10.17509/edusentris.v2i2.169.

Martusa, R. (2009). "Peranan Environmental Accounting Terhadap Global Warming." Jurnal Akuntansi, 1(2):164-79.

Muhammad, Afandi, Badarudin. (2011). Perencanaan Pembelajaran Di Sekolah Dasar Dengan Memasukkan Pendidikan Budaya Dan Karakter Bangsa. Bandung: Alfabeta.

Munadi, Y. (2012). Media Pembelajaran. Jakarta: Gaung persada.

Nurasih, Prilia, Wahyuni, Leksono. (2020). Pengembangan Majalah Invertebrata Sebagai Sumber Belajar Siswa SMA Pada Subkonsep Invertebrata. Gagasan Pendidikan Indonesia, 1(2):87. doi: 10.30870/gpi.v1i2.9886.

Pratiwi, Nurjannah, Gardjito, Hamidah. (2018). Pengembangan Majalah Biologi Sebagai Media Pembelajaran Pada Pokokbahasan Protista Kelas X Mia Di Sma N 7 Kota Jambi. Biodik, 3(1):27-34. doi: 10.22437/bio.v3i1.4880.

Savitri dan Alda. (2019). Pengembangan Majalah Elektronik Berbasis Literasi Matematika Untuk Siswa SMP kelas VII. Journal of Chemical Information and Modeling, 53(9):1689-99.

Sugioyono. (2019). Metode Penelitian Dan Pengembangan. Bandung: CV. Alfabeta. Sujana dan Cong. (2019). Fungsi Dan Tujuan Pendidikan Indonesia. Adi Widya: Jurnal Pendidikan Dasar, 4(1):29. doi: 10.25078/aw.v4i1.927.

Yulianto dan Rohaeti. (2013). Pengembangan Majalah Fisika Materi Pokok Fluida Bergerak Sebagai Alternatif Sumber Belajar Mandiri Untuk Meningkatkan Hasil Belajar Mandiri Fisika Peserta Didik Kelas XI. Jurnal Pendidikan Sains Universitas Negeri Semarang. 